\title{
3. THERMAL HISTORY OF JAPAN SEA SEDIMENTS FROM ISOTOPIC STUDIES OF DIAGENETIC SILICA AND ASSOCIATED PORE WATERS ${ }^{1}$
}

\author{
Kenneth A. Pisciotto, ${ }^{2}$ Richard W. Murray, ${ }^{3}$ and Hans-Jurgen Brumsack ${ }^{4}$
}

\begin{abstract}
Over a broad region of the eastern Japan Sea, Neogene opaline diatomaceous sediments alter with depth to hard porcellanites and cherts composed of opal-CT and quartz. We examined the oxygen isotopic compositions of these diagenetic silica minerals at four widely spaced sites occupied during ODP Leg 127 in order to investigate the thermal history of the region. Formation temperatures computed from these isotopic data range from $22^{\circ}$ to $68^{\circ} \mathrm{C}$ for opal-CT and from $44^{\circ}$ to $92^{\circ} \mathrm{C}$ for diagenetic quartz, quite similar to temperature ranges estimated from the extrapolated modern gradients, $36^{\circ}-43^{\circ} \mathrm{C}$ and $49^{\circ}-64^{\circ} \mathrm{C}$, respectively. At each site the isotopic temperature values cluster near the extrapolated ambient sediment temperatures. As a first approximation, the similarities suggest that the positions of the silica transformations in the basin are controlled by the present thermal regime.

In detail, isotopic and ambient temperatures differ. If these differences are real, then they reflect variations in the thermal histories at these sites. At Sites 794 and 797 in the Yamato Basin, isotopic temperatures and gradients computed from these data are lower than or comparable to ambient temperatures and gradients. We suggest that the silica zones have roughly equilibrated with the modern gradients at these localities. At Site 795 in the Japan Basin, isotopic temperatures are also lower than ambient sediment temperatures at comparable depths, but the gradient computed from the isotopic temperatures is higher than the present measured gradient. For both scenarios to hold, the silica zones must have formed under initially high gradients during the early post-rift period at this locality. These zones were then rapidly buried and have yet to equilibrate with the modern lower gradient. At Site 796 on Okushiri Ridge, isotopic temperatures exceed present temperatures as expected for an area of recent uplift. The gradient computed from our isotopic data and the thickness of the opal-CT zone indicate a higher gradient than at present at this site, apparently reflecting higher heat fluxes during the early post-rift period or recent frictional heating from nearby reverse fault activity.
\end{abstract}

\section{INTRODUCTION}

\section{Purpose}

In this study we use oxygen isotopic compositions of diagenetic silica and associated pore waters to investigate the thermal history of Neogene diatomaceous sediments in the eastern Japan Sea. In particular, we compute past thermal gradients at four Leg 127 Ocean Drilling Program (ODP) sites from isotopically determined formation temperatures of opal-CT and diagenetic quartz (Fig. 1). Our premise is that any differences between the calculated values and the present thermal gradients elucidate the thermal history of the sediments and the basin.

\section{Background}

One of the principal findings of the recent ODP drilling in the eastern Japan Sea was that diagenetic processes significantly affect the Neogene sediments at all sites (Tamaki, Pisciotto, Allan, et al., 1990; Ingle, Suyehiro, von Breymann, et al., 1990). The most pronounced and widespread of these processes is the thorough alteration of opaline diatomaceous sediments to hard porcellanites and cherts. Three successive silica mineral zones correspond to lithologic changes. With increasing depth of burial they are the opal-A, opal-CT, and quartz zones. The opal-A/opal-CT transition is the most conspicuous boundary in the study area. It corresponds to a marked change in all physical properties of the sediments and is distinctly manifested in the downhole logs and on seismic reflection profiles. The opal-CT/quartz transition also corresponds to physical property changes in the sediments, but the effects are less pronounced.

\footnotetext{
${ }^{1}$ Pisciotto, K. A., Ingle, J. C., Jr., von Breymann, M. T., Barron, J., et al., 1992. Proc. ODP, Sci. Results, 127/128, Pt. 1: College Station, TX (Ocean Drilling Program).

${ }^{2}$ Consulting Geologist, 7547 Terrace Drive, El Cerrito, CA 94530, U.S.A.

${ }^{3}$ Department of Geology and Geophysics, University of California, Berkeley, CA 94720 , U.S.A.

${ }_{4}^{4}$ Geochemisches Institut, Goldschmidtstrasse 1, D-3400 Göttingen, Federal Republic
} of Germany.
Silica mineral transformations are largely time- and temperature-controlled, irreversible reactions (Mizutani, 1970), somewhat analogous to the transformations of organic matter to hydrocarbons. Each transformation involves dissolution of the less ordered silica polymorph and precipitation of the next, more ordered form (e.g., Kastner, 1981, and references therein). There is some evidence, particularly from the Southern Ocean, that opal-CT has formed at shallow burial depths $(5-15 \mathrm{~m})$ and at low temperatures $\left(<5^{\circ} \mathrm{C}\right)$ (Weaver and Wise, 1973; Bohrmann et al., 1990; Botz and Bohrmann, in press). It is, however, more common for the silica transformations to occur at somewhat greater burial depths $(100+\mathrm{m})$ and temperature ranges $\left(20^{\circ}-110^{\circ} \mathrm{C}\right)$, with each solution-precipitation front spanning several tens of meters (e.g., Murata and Larson, 1976; Murata et al., 1977; Pisciotto, 1981a, b).

Oxygen isotopes are a useful tool for estimating formation temperatures of silica transformations at selected localities, provided that samples of both the silica and equilibrating fluids are available. The $\delta^{18} \mathrm{O}$ values of silica and water are related to temperature through experimentally determined fractionation expressions (see summaries in Pisciotto (1981a) and Leclerc and Labeyrie (1987)). Murata et al. (1977) and Pisciotto (1981a, b) have shown that the oxygen isotopic composition of silica changes abruptly at the transformation boundaries, suggesting that opal-CT acquires its $\delta^{18} \mathrm{O}$ value through equilibration with the surrounding pore water at the opal-A/opal-CT transformation boundary and retains this isotopic signature until it dissolves and precipitates as diagenetic quartz at the opal-CT/quartz boundary, where it acquires a new $\delta^{18} \mathrm{O}$ value through equilibration with the pore water (Fig. 2). Thus for any siliceous sedimentary section, the mean $\delta^{18} \mathrm{O}$ values of opal-CT and diagenetic quartz provide estimates of temperature that can be used to compute past gradients. In particular, the estimated temperature difference between the top and base of the opal-CT zone, coupled with the thickness of the zone, provides an estimate of the past thermal gradient. Further, these gradients should represent historical maximums because the silica transformations are irreversible.

The Leg 127 drilling offered a unique opportunity to obtain both silica and associated water samples for isotopic analyses at sites with 


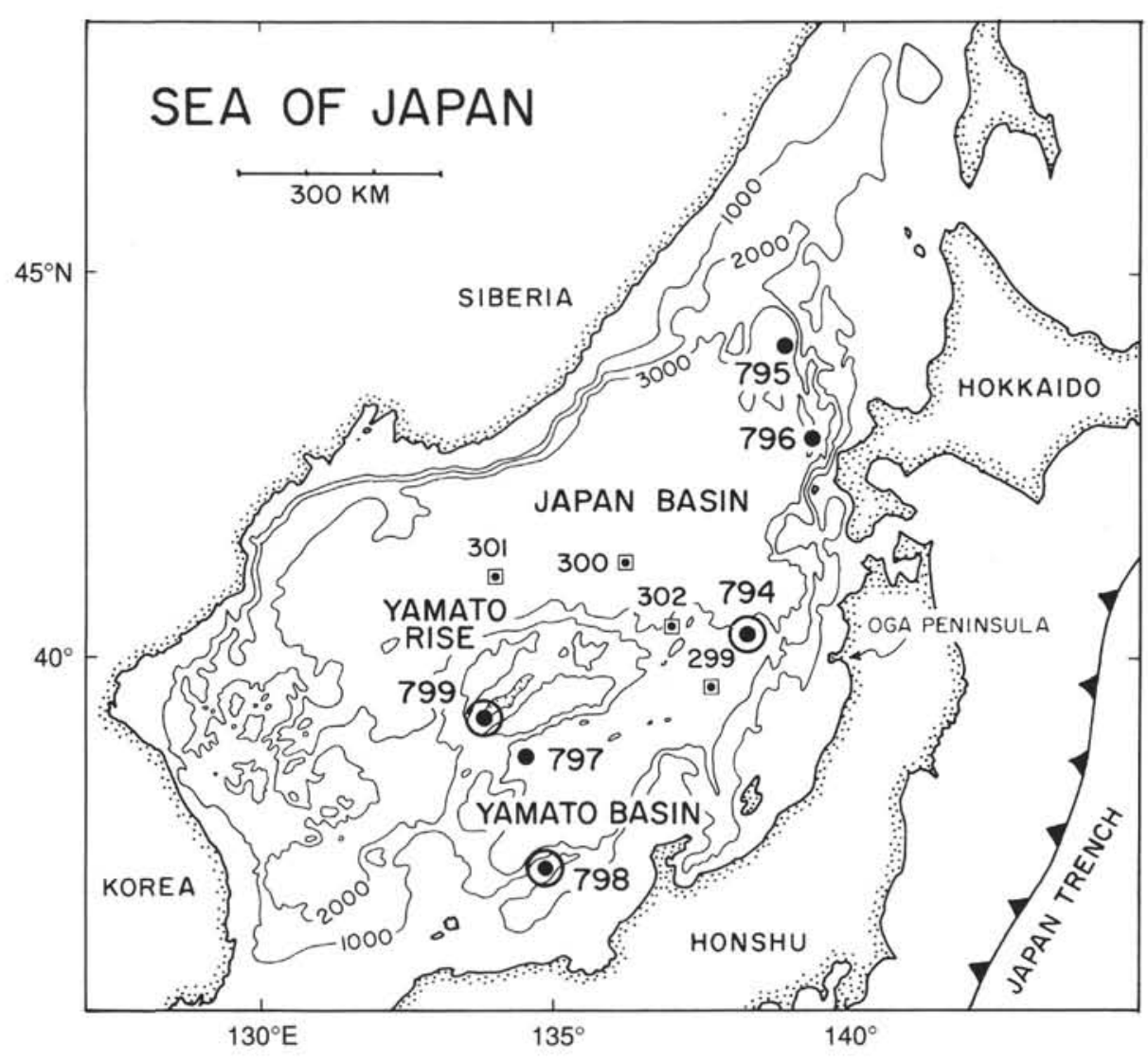

Figure 1. Location map showing ODP Sites 794-797 (Leg 127) and 798-799 (Leg 128) and DSDP Sites 299-302 (Leg 31).

accurate subsurface temperature measurements (Fig. 1; Table 1). At Sites 794 and 797 in the Yamato Basin and at Site 795 in the Japan Basin, the sedimentary sections are apparently intact with little or no overburden removed. Here the opal-A/opal-CT and opal-CT/quartz boundaries occur at 290 to $325 \mathrm{mbsf}$ and 390 to $471 \mathrm{mbsf}$, respectively, and correspond to respective present subsurface temperatures in the ranges of $36^{\circ}-43^{\circ} \mathrm{C}$

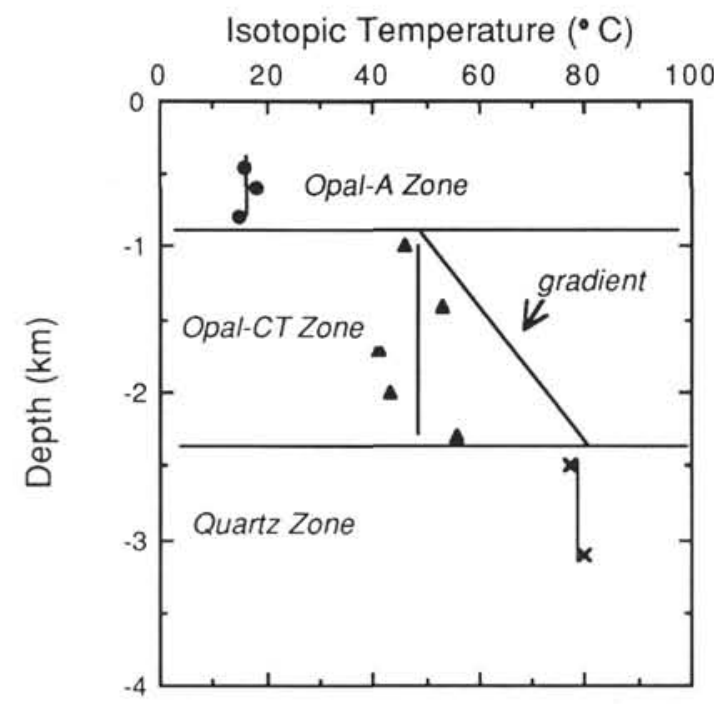

Figure 2. Schematic relation between depth and isotopic temperatures for

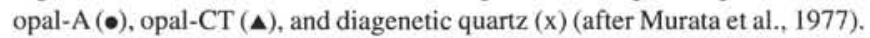
Vertical lines represent mean values used in computation of the thermal gradient. and $49^{\circ}-64^{\circ} \mathrm{C}$. For these sites we anticipated several possible scenarios based on our isotopic data. First, if the mean temperatures and thermal gradients determined from isotopic data differ significantly from the present gradients computed from the downhole temperature measurements, then we stood to learn much about the thermal history of the eastern Japan Sea. Alternatively, if these sedimentary sections experienced no greater thermal gradients than the present values, then the isotopically determined mean temperatures and gradients should match the present ones measured using the sediment temperature probe. In this case the data would both confirm the recent temperature history and prove useful in assessing the various published fractionation expressions. In contrast, Site 796 lies on a part of Okushiri Ridge that has been uplifted as recently as $1.8 \mathrm{Ma}$. Here the opal-A/opal-CT and opal-CT/quartz transitions occur at relatively shallow burial depths of 225 and 325 mbsf, respectively, and correspond to respective present subsurface temperatures of $40^{\circ} \mathrm{C}$ and $58^{\circ} \mathrm{C}$. The similarity of these temperatures to those at the basinal sites suggests that the silica mineral transformations have adjusted to the high temperature gradient and recent uplift at this locality. Our goal at this site was to provide an independent measure of its history.

\section{METHODS}

\section{Sediments}

We based our initial selection of 74 sediment samples for this study on lithologic descriptions and bulk X-ray diffraction (XRD) data acquired routinely during Leg 127 . All selected samples were X-rayed again to determine the abundance and relative amounts of diagenetic opal-CT and quartz. From this population, we derived a subset of 49 representative samples deemed to have sufficient diagenetic silica for isotopic analysis. In addition to biogenic and diagenetic silica, most 
samples contained some clays and carbonate, as well as detrital quartz and feldspar. Thus it was necessary to isolate opal-CT and quartz from these rock and sediment samples to eliminate the unwanted oxygen contributions from these other minerals. To achieve this, we used a proven chemical separation method which does not significantly affect the isotopic values of the isolated silica minerals (Pisciotto, 1978, 1981a). The method involves pyrosulfate fusion and treatment with acids to remove all mineral components including opal-A, but not opal-CT or quartz. Sodium hydroxide is used to dissolve opal-CT from splits of samples which contain both opal-CT and quartz. Unfortunately, the method does not distinguish or isolate diagenetic quartz from detrital quartz. The isotopic value of any sample containing both types of quartz will vary directly with their respective $\delta^{18} \mathrm{O}$ values and relative weight percentages (Pisciotto, 1978, p. 429-430). Therefore, we made thin sections of pertinent samples in order to visually assess the significance of the detrital quartz component. Our specific assessments of each sample and the estimated isotopic uncertainties due to detrital quartz contamination are discussed in the Results section.

All oxygen isotopic analyses of silica were done commercially at Geochron Laboratories (Krueger Laboratories, Inc., Cambridge, MA). We report the results using the standard notation in parts per thousand $(\mathrm{o} \%$ ) relative to Standard Mean Ocean Water (SMOW). Differences between duplicate analyses averaged $0.6 \%$. For those samples containing both opal-CT and quartz, we calculated the oxygen isotopic value of the opal-CT using the relation

$$
\begin{aligned}
& \delta^{18} \mathrm{O} \text { opal-CT }= \\
& {\left[\frac{\left(\delta^{18} \mathrm{O} \text { opal-CT }+ \text { quartz }\right)-\left(\text { wt } \% \text { quartz } \times \delta^{18} \mathrm{O} \text { quartz }\right)}{w \mathrm{w} \% \text { opal-CT }}\right]}
\end{aligned}
$$

(Pisciotto, 1981a). We made no adjustment for the apparent minor $\delta^{18} \mathrm{O}$ depletion $(\sim 0.8 \mathrm{o} \%$ o) of opal-CT due to fusion (Pisciotto, 1981a).

\section{Pore Waters}

Interstitial water samples were obtained at each hole drilled during Leg 127 by squeezing 10-cm-long, whole-round sediment samples immediately upon retrieval using a conventional stainless steel device and a newly developed plastic-lined squeezer (Manheim and Sayles, 1974; Tamaki, Pisciotto, Allan, et al., 1990; Brumsack et al., this volume). Sampling frequency averaged one sample per $10 \mathrm{~m}$ of section in the soft sediments and one sample every $10-40 \mathrm{~m}$ in the underlying indurated sediments at each site. Special effort was made to obtain water samples as close as possible to the diagenetic silica boundaries. A total of 97 water samples, each $0.5-1 \mathrm{~mL}$ in volume and sealed in glass ampules, was taken for this study. We acquired isotopic data on 85 of these samples.

All oxygen isotopic analyses of pore waters were acquired at the Geochemisches Institut in Göttingen (Federal Republic of Germany). Because of a change in safety regulations at the Göttingen laboratory during our analyses, we were forced to use two different methods to extract oxygen from the pore water samples. In the first case, we reacted $10 \mu \mathrm{L}$ volume samples with $\mathrm{BrF} 5$ and converted the oxygen to $\mathrm{CO}_{2}$ (Clayton and Mayeda, 1963); this method was used for all samples from Site 795 . Following the safety regulation change, we developed a micro-equilibration technique for $100 \mu \mathrm{L}$ volume samples patterned after Kishima and Sakai (1980) to analyze the remaining samples from Sites 794, 796, and 797. This technique relies upon the equilibrium exchange of oxygen in a water sample with $\mathrm{CO}_{2}$ of known isotopic composition. All samples were allowed to exchange for a period of $48 \mathrm{hr}$ at $25^{\circ} \mathrm{C}$, and we analyzed all $\mathrm{CO}_{2}$ gas samples produced by both methods using a Finnigan MAT 251 mass spectrometer. We confirmed the accuracy of the results for both methods against three separate international standards (SMOW, SLAP, and GISP); overall precision is $\pm 0.3 \%$. As for the sediment data, we report the pore water results using the standard notation in parts per thousand $(\mathrm{o} / \mathrm{oo})$ relative to SMOW.
Table 1. Measured downhole temperatures and com-

\begin{tabular}{|c|c|c|c|}
\hline $\begin{array}{l}\text { Site/ } \\
\text { Hole }\end{array}$ & $\begin{array}{l}\text { Depth } \\
\text { (mbsf) }\end{array}$ & $\begin{array}{c}\text { Temperature } \\
\left({ }^{\circ} \mathrm{C}\right)\end{array}$ & $\begin{array}{l}\text { Gradient } \\
\left({ }^{\circ} \mathrm{C} / \mathrm{km}\right)\end{array}$ \\
\hline $794 \mathrm{~A}$ & 0.0 & 0.20 & \\
\hline $794 \mathrm{~A}$ & 26.8 & 3.83 & \\
\hline $794 \mathrm{~A}$ & 55.3 & 6.91 & \\
\hline $794 \mathrm{~A}$ & 74.3 & 9.72 & \\
\hline $794 \mathrm{~A}$ & 112.3 & 13.42 & \\
\hline $794 \mathrm{~A}$ & 140.8 & 17.00 & \\
\hline $794 \mathrm{~A}$ & 169.5 & 19.90 & \\
\hline $794 \mathrm{~A}$ & 208.2 & 26.42 & \\
\hline $794 \mathrm{~A}$ & 237.6 & 29.30 & \\
\hline $794 \mathrm{~A}$ & 266.4 & 33.78 & \\
\hline $794 \mathrm{~A}$ & 294.5 & 37.50 & \\
\hline 794 & & & 126 \\
\hline $795 \mathrm{~A}$ & 0.0 & 0.20 & \\
\hline $795 \mathrm{~A}$ & 29.3 & 3.18 & \\
\hline $795 \mathrm{~A}$ & 57.8 & 7.93 & \\
\hline $795 \mathrm{~A}$ & 86.3 & 11.83 & \\
\hline $795 \mathrm{~A}$ & 143.5 & 18.85 & \\
\hline $795 \mathrm{~A}$ & 163.4 & 21.54 & \\
\hline 795 & & & 135 \\
\hline $796 \mathrm{~A}$ & 23.2 & 3.81 & \\
\hline $796 \mathrm{~B}$ & 60.5 & 11.22 & \\
\hline $796 \mathrm{~B}$ & 79.8 & 13.98 & \\
\hline 796 & & & 178 \\
\hline $797 \mathrm{~B}$ & 0.0 & 0.20 & \\
\hline $797 \mathrm{~B}$ & 25.9 & 3.10 & \\
\hline $797 \mathrm{~B}$ & 54.4 & 7.00 & \\
\hline $797 \mathrm{~B}$ & 82.9 & 10.37 & \\
\hline $797 \mathrm{~B}$ & 138.9 & 17.27 & \\
\hline $797 \mathrm{~B}$ & 185.5 & 22.57 & \\
\hline 797 & & & 121 \\
\hline
\end{tabular}
puted thermal gradients at ODP Sites 794-797.

\section{RESULTS}

Tables 2 and 3 summarize all oxygen isotopic values and relevant compositional data acquired for pore water samples and siliceous sediments in this study. The pore waters show a range in $\delta^{18} \mathrm{O}$ values of $0 \%$ to $7.7 \%$ at all four sites. The $\delta^{18} \mathrm{O}$ values for opal-CT and quartz are much higher. Opal-CT values range from $22.5 \%$ o to $31.2 \%$. In contrast, quartz samples have a much broader isotopic range, $2.0 \%$ to $25.6 \%$, reflecting the inclusion of both diagenetic and detrital quartz. We used published isotopic data, textural information from hand specimens and thin sections, compositional data derived from XRD of the original bulk sediment samples, and position within the silica mineral zones to distinguish between the two types of quartz in these samples. With one exception, all quartz samples occurring within the opal-CT zones have light $\delta^{18} \mathrm{O}$ values, generally between 2 and about $18 \%$ o (Table 2). These values are typical of igneous and metamorphic quartz and reflect high formation temperatures. Combining this evidence with textural information, which demonstrates the presence of very fine-grained detrital quartz and feldspar in the untreated samples, we conclude that the quartz in these samples is mostly detrital. We have footnoted these values in Table 3 and do not consider them further in this paper. By inference, those quartz samples with $\delta^{18} \mathrm{O}$ values of $18 \%$ or less and lying wholly within the quartz zones are considered to comprise mostly detrital quartz. These have also been identified with asterisks and are not considered further. The remaining quartz samples have $\delta^{18} \mathrm{O}$ values in the range $20.6 \%$ to $25.6 \%$. Coupled with textural and compositional data, these heavy values indicate that these samples comprise mostly diagenetic quartz, with only insignificant amounts $(<5 \%)$ of silt-size detrital quartz. We use these values in our interpretations. 
Table 2. Oxygen isotopes of pore-water samples at ODP Sites 794-797.

\begin{tabular}{|c|c|c|c|c|c|}
\hline $\begin{array}{l}\text { Hole, core, section, } \\
\text { interval }(\mathrm{cm})\end{array}$ & $\begin{array}{l}\text { Depth } \\
\text { (mbsf) }\end{array}$ & $\begin{array}{c}\delta^{18} \mathrm{O} \text { Water } \\
(\%)\end{array}$ & $\begin{array}{l}\text { Hole, core, section, } \\
\text { interval }(\mathrm{cm})\end{array}$ & $\begin{array}{l}\text { Depth } \\
\text { (mbsf) }\end{array}$ & $\begin{array}{c}\delta^{18} \mathrm{O} \text { Water } \\
(\% / \%)\end{array}$ \\
\hline $794 \mathrm{~A}-3 \mathrm{H}-5,145$ & 23.8 & -0.22 & $795 B-31 R-5,146-150$ & 662.0 & -3.10 \\
\hline $794 \mathrm{~A}-4 \mathrm{H}-4,147.5$ & 31.8 & -0.92 & $796 \mathrm{~A}-1 \mathrm{H}-2,55-60$ & 2.1 & 0.04 \\
\hline $794 \mathrm{~A}-5 \mathrm{H}-4,147.5$ & 41.3 & -1.00 & $796 \mathrm{~A}-2 \mathrm{H}-4,145-150$ & 9.2 & -0.55 \\
\hline $794 \mathrm{~A}-6 \mathrm{H}-4,145$ & 50.8 & -1.08 & $796 \mathrm{~A}-3 \mathrm{H}-1,140-150$ & 14.2 & -1.01 \\
\hline $794 \mathrm{~A}-9 \mathrm{H}-4,145$ & 79.3 & -1.06 & $796 \mathrm{~A}-4 \mathrm{H}-3,145-150$ & 26.7 & -1.48 \\
\hline $794 \mathrm{~A}-12 \mathrm{H}-4,145$ & 88.8 & -1.55 & $796 \mathrm{~A}-5 \mathrm{H}-5,145-150$ & 39.2 & -1.35 \\
\hline $794 \mathrm{~A}-19 \mathrm{X}-4,145$ & 107.8 & -2.16 & $796 \mathrm{~A}-6 \mathrm{H}-6,140-150$ & 50.2 & -1.27 \\
\hline $794 \mathrm{~A}-22 \mathrm{X}-4,145$ & 203.5 & -2.68 & $796 \mathrm{~A}-8 \mathrm{H}-5,145-150$ & 58.7 & -1.19 \\
\hline $794 \mathrm{~A}-25 \mathrm{X}-4,145$ & 232.5 & -3.16 & $796 \mathrm{~A}-9 \mathrm{X}-2,140-150$ & 61.7 & -1.30 \\
\hline $794 \mathrm{~A}-29 \mathrm{X}-4,145$ & 271.4 & -3.91 & $796 \mathrm{~A}-11 \mathrm{X}-1,145-150$ & 79.8 & -1.11 \\
\hline $794 \mathrm{~A}-33 \mathrm{X}-2,145$ & 309.3 & -4.12 & $796 \mathrm{~A}-14 \mathrm{X}-2,140-150$ & 110.6 & -1.17 \\
\hline $794 A-36 X-4,145$ & 337.9 & -4.13 & $796 \mathrm{~A}-17 \mathrm{X}-2,140-150$ & 139.5 & -1.25 \\
\hline $794 \mathrm{~B}-12 \mathrm{R}-2,145$ & 406.5 & -4.59 & $796 \mathrm{~A}-21 \mathrm{X}-4,140-150$ & 181.0 & -1.18 \\
\hline $794 \mathrm{~B}-18 \mathrm{R}-4,145$ & 468.6 & -4.27 & $796 \mathrm{~A}-24 \mathrm{X}-1,140-150$ & 205.6 & -1.51 \\
\hline 794B-21R-3, 145 & 496.2 & $-4,41$ & $796 \mathrm{~B}-12 \mathrm{R}-1,140-150$ & 263.8 & -1.51 \\
\hline 794B-24R-2, 145 & 523.7 & -4.81 & 796B-15R-2, 140-150 & 294.3 & -1.4 \\
\hline $795 \mathrm{~A}-1 \mathrm{H}-4,140-145$ & 6.0 & -0.20 & $797 \mathrm{~B}-1 \mathrm{H}-2,140-150$ & 3.0 & -0.37 \\
\hline $795 \mathrm{~A}-2 \mathrm{H}-4,145-150$ & 15.3 & -0.70 & $797 \mathrm{~B}-2 \mathrm{H}-4,145-150$ & 11.9 & -0.84 \\
\hline $795 \mathrm{~A}-3 \mathrm{H}-4,140-145$ & 24.8 & -0.80 & $797 \mathrm{~B}-3 \mathrm{H}-5,140-150$ & 22.9 & -1.35 \\
\hline $795 \mathrm{~A}-4 \mathrm{H}-4,145-150$ & 34.8 & -0.40 & $797 \mathrm{~B}-4 \mathrm{H}-4,145-150$ & 30.9 & -1.13 \\
\hline $795 \mathrm{~A}-5 \mathrm{H}-4,145-150$ & 43.2 & -1.10 & $797 \mathrm{~B}-5 \mathrm{H}-4,145-150$ & 40.4 & -1.06 \\
\hline $795 \mathrm{~A}-7 \mathrm{H}-4,145-150$ & 62.8 & -1.20 & $797 \mathrm{~B}-6 \mathrm{H}-4,140-150$ & 49.9 & -1.39 \\
\hline $795 \mathrm{~A}-8 \mathrm{H}-4,145-150$ & 72.3 & -1.30 & $797 \mathrm{~B}-7 \mathrm{H}-4,145-150$ & 59.4 & -1.49 \\
\hline $795 \mathrm{~A}-10 \mathrm{H}-1,145-150$ & 86.8 & -1.10 & 797B-8H-4, 145-150 & 68.9 & -1.25 \\
\hline $795 \mathrm{~A}-12 \mathrm{H}-4,140-145$ & 110.2 & -2.20 & $797 \mathrm{~B}-9 \mathrm{H}-4,140-150$ & 78.4 & -1.87 \\
\hline $795 \mathrm{~A}-15 \mathrm{H}-4,140-145$ & 138.8 & -1.60 & $797 \mathrm{~B}-10 \mathrm{H}-4,145-150$ & 87.9 & -1.61 \\
\hline $795 \mathrm{~A}-18 \mathrm{H}-4,140-145$ & 158.8 & -2.20 & $797 \mathrm{~B}-12 \mathrm{H}-4,140-150$ & 106.9 & -1.57 \\
\hline $795 \mathrm{~A}-21 \mathrm{X}-4,140-145$ & 187.6 & -2.70 & $797 \mathrm{~B}-15 \mathrm{H}-4,140-150$ & 135.4 & -2.32 \\
\hline $795 \mathrm{~A}-25 \mathrm{X}-3,140-145$ & 224.8 & -3.20 & $797 \mathrm{~B}-18 \mathrm{H}-4,140-150$ & 163.9 & -2.92 \\
\hline $795 \mathrm{~A}-29 \mathrm{X}-2,140-145$ & 262.4 & -3.00 & $797 \mathrm{~B}-21 \mathrm{X}-4,140-150$ & 191.5 & -4.05 \\
\hline $795 \mathrm{~A}-30 \mathrm{X}-2,145-150$ & 272.3 & -3.50 & $797 \mathrm{~B}-24 \mathrm{X}-5,140-150$ & 221.8 & -4.92 \\
\hline $795 \mathrm{~A}-31 \mathrm{X}-4,145-150$ & 285.1 & -4.70 & $797 \mathrm{~B}-27 \mathrm{X}-6,140-150$ & 252.4 & -3.97 \\
\hline $795 A-34 X-5,140-145$ & 315.4 & -4.10 & $797 \mathrm{~B}-28 \mathrm{X}-1,145-150$ & 254.6 & -4.41 \\
\hline $795 \mathrm{~A}-35 \mathrm{X}-2,145-150$ & 320.6 & -4.90 & $797 \mathrm{~B}-29 \mathrm{X}-1,145-150$ & 274.0 & -4.80 \\
\hline $795 \mathrm{~A}-37 \mathrm{X}-1,140-150$ & 339.8 & -4.50 & $797 \mathrm{~B}-30 \mathrm{X}-4,140-150$ & 288.1 & -6.24 \\
\hline $795 B-1 R-1,140-150$ & 366.6 & -5.10 & $797 \mathrm{~B}-32 \mathrm{X}-3,145-150$ & 296.4 & -5.45 \\
\hline $795 B-13 R-2,140-150$ & 483.9 & -4.80 & $797 \mathrm{~B}-33 \mathrm{X}-2,140-150$ & 304.4 & -4.90 \\
\hline $795 \mathrm{~B}-16 \mathrm{R}-1,140-150$ & 511.2 & -3.90 & $797 \mathrm{~B}-37 \mathrm{X}-4,140-150$ & 346.3 & -4.60 \\
\hline $795 \mathrm{~B}-19 \mathrm{R}-1,140-150$ & 540.1 & -3.70 & $797 \mathrm{~B}-40 \mathrm{X}-1,56-66$ & 370.0 & -5.99 \\
\hline $795 \mathrm{~B}-22 \mathrm{R}-2,89-94$ & 570.1 & -3.80 & $797 \mathrm{~B}-49 \mathrm{X}-3,145-150$ & 460.0 & -6.50 \\
\hline $795 \mathrm{~B}-25 \mathrm{R}-1,140-150$ & 598.1 & -3.70 & $797 \mathrm{~B}-51 \mathrm{X}-4,140-150$ & 480.9 & -6.43 \\
\hline $795 \mathrm{~B}-28 \mathrm{R}-2,140-150$ & 628.6 & -4.30 & $797 C-5 R-2,140-150$ & 525.0 & -7.69 \\
\hline
\end{tabular}

Figure 3 plots $\delta^{18} \mathrm{O}$ depth profiles for pore waters and diagenetic silica at Leg 127 sites. In nearly all cases, the general pattern is a decrease in $\delta^{18} \mathrm{O}$ values with depth. At Sites 794, 795, and 797, pore water depletion gradients between the sea floor and the top of the opal-CT zone average $-1.4 \%$ o per $100 \mathrm{~m}$. Below the top of the opal-CT zone, pore water $\delta^{18} \mathrm{O}$ values either decrease less rapidly, as at Sites 794 and 797, or show a marked increase, as at Site 795. At Site 796 , the pore water d 180 values decrease from $0.04 \%$ o to $-1.01 \%$ between the seafloor and 15 mbsf and then deplete slowly at a rate of $-0.2 \%$ o per $100 \mathrm{~m}$ to about $300 \mathrm{mbsf}$.

In contrast with the pore waters, the oxygen isotopic profiles for diagenetic silica are less well constrained and show considerable scatter (Fig. 3). Despite the scatter, Sites 795, 796, and 797 show that average $\delta^{18} \mathrm{O}$ values for opal-CT are always heavier than those for the underlying diagenetic quartz at each site, similar to the findings of Murata et al. (1977) and Pisciotto (1981a). The differences range from 4.3 to $7.9 \%$ o. In contrast, there is no significant difference between $\delta^{18} \mathrm{O}$ values for opal-CT and quartz at Site 794 .

\section{DISCUSSION}

\section{Pore Waters}

The pore water $\delta^{18} \mathrm{O}$ profiles for Leg 127 sites are broadly similar to profiles for many DSDP sites (see summary in Pisciotto (1981b, Fig. 9)). At most of these localities, pore water $\delta^{18} \mathrm{O}$ values decrease from about $0 \%$ just below the seafloor at rate of about $-0.2 \%$ per $100 \mathrm{~m}$ to $-1.0 \%$ per $100 \mathrm{~m}$. At the Leg 127 sites, we ascribe the significant decreases in pore water $\delta^{18} \mathrm{O}$ values down to the top of the opal-CT zone largely to the alteration of volcanic ash layers (e.g., Perry et al., 1976; Gieskes, 1981; Gieskes and Lawrence, 1981). In contrast, the marked change in slope of these profiles at the opal-A/opal-CT transition at Sites 794, 795, and 797 reflects exchange with isotopically heavy oxygen made available through the dissolution of abundant biogenic silica as well as contribution of heavy oxygen from basement alteration and possibly advective transport (e.g., Tamaki, Pisciotto, Allan, et al., 1990; Brumsack and Zuelger, this volume; Murray et al., this volume; Murray and Brumsack, this volume). The absence of this slope change at Site 796 is probably due to the relatively low abundance of biogenic silica in the sediments and to the presence of gas hydrates which, upon dissolution, would also affect pore water isotopic compositions (Jenden and Gieskes, 1983).

\section{Isotopic Temperatures and Thermal Gradients}

We computed all silica formation temperatures for this study using the fractionation expression of Kita et al. (1985). We chose this relation because (1) it relates the oxygen isotopic compositions of amorphous silica and water over a temperature range similar to that observed and proposed for the diagenetic silica transformations and (2) it best matches the low-temperature expression of Leclerc and Labeyrie (1987) for biogenic silica and water and the widely used, higher temperature relation of Clayton et al. (1972) for quartz and 
Table 3. Lithology, opal-CT and quartz percentages, and oxygen isotopes of samples of this study, ODP Sites 794-797.

\begin{tabular}{|c|c|c|c|c|c|c|c|}
\hline $\begin{array}{l}\text { Hole, core, section, } \\
\text { interval }(\mathrm{cm})\end{array}$ & $\begin{array}{l}\text { Depth } \\
\text { (mbsf) }\end{array}$ & Lithology & Wt.\% Opal-CT & Wt.\% Quartz & $\underset{(\% / \infty)}{\delta^{18} \mathrm{O} \text { Opal-CT }+ \text { Quartz }}$ & $\begin{array}{c}\delta^{18} \mathrm{O} \text { Opal-CT } \\
(\% \%)\end{array}$ & $\begin{array}{c}\delta^{18} \text { Quartz } \\
(\% / \infty)\end{array}$ \\
\hline $794 A-32 X-3,146-150$ & 297.96 & Chert/porcellanite & 83 & 17 & 22.5 & 24.1 & ${ }^{\mathrm{a}} 14.5$ \\
\hline $794 \mathrm{~A}-35 \mathrm{X}-1,28-32$ & 322.48 & Mudstone & 0 & 100 & 18.2 & - & 18.2 \\
\hline $794 \mathrm{~B}-37 \mathrm{X}-1,54-58$ & 342.14 & Siliceous mudstone & 85 & 15 & 21.7 & 23.4 & ${ }^{\mathrm{a}} 12.0$ \\
\hline 794B-7R-1, $14-18$ & 356.74 & Porcellanite & 84 & 16 & 24.0 & 26.0 & ${ }^{a} 13.6$ \\
\hline $794 \mathrm{~B}-9 \mathrm{R}-1,56-60$ & 376.56 & Porcellanite & 78 & 22 & 23.2 & 25.4 & 15.5 \\
\hline $794 \mathrm{~B}-10 \mathrm{R}-1,16-20$ & 385.76 & Porcellanite & 89 & 11 & 26.3 & 27.8 & ${ }^{\mathrm{a}} 13.9$ \\
\hline 794B-1 IR-CC, 16-20 & 396.06 & Siliceous mudstone & 0 & 100 & 25.6 & - & 25.6 \\
\hline $794 \mathrm{~B}-12 \mathrm{R}-2,7-11$ & 406.47 & Siliceous mudstone & 0 & 100 & 23.7 & - & 23.7 \\
\hline $794 \mathrm{~B}-15 \mathrm{R}-2,28-32$ & 435.58 & Siliceous mudstone & 0 & 100 & 24.0 & - & 24.0 \\
\hline $794 B-18 R-5,6-10$ & 468.66 & Siliceous mudstone & 0 & 100 & 25.1 & - & 25.1 \\
\hline $795 A-35 X-6,5-9$ & 325.15 & Chert/porcellanite & 91 & 9 & 29.1 & 29.7 & 23.1 \\
\hline $795 \mathrm{~A}-37 \mathrm{X}-1,81-85$ & 337.71 & Siliceous mudstone & 82 & 12 & 27.3 & 31.2 & ${ }^{\mathrm{a}} 14.5$ \\
\hline $795 B-5 R-1,90-94$ & 405.00 & Siliceous mudstone & 90 & 10 & 26.7 & 28.1 & ${ }^{\mathrm{a}} 13.9$ \\
\hline $795 \mathrm{~B}-12 \mathrm{R}-3,54-58$ & 474.94 & Mudstone & 0 & 100 & 23.5 & - & 23.5 \\
\hline $795 \mathrm{~B}-13 \mathrm{R}-3,1-5$ & 484.01 & Siliceous mudstone & 0 & 100 & 22.0 & - & 22.0 \\
\hline $795 \mathrm{~B}-16 \mathrm{R}-1,127-131$ & 510.97 & Porcellanite & 0 & 100 & 22.5 & - & 22.5 \\
\hline 795B-17R-1, 91-94 & 520.31 & Siliceous mudstone & 0 & 100 & 20.8 & - & 20.8 \\
\hline $796 \mathrm{~A}-26 \mathrm{X}-2,101-105$ & 226.01 & Mudstone & 60 & 40 & 21.2 & 25.4 & ${ }^{\mathrm{a}} 14.9$ \\
\hline $796 \mathrm{~B}-11 \mathrm{R}-2,62-66$ & 254.82 & Mudstone & 63 & 37 & 20.9 & 23.8 & 16.0 \\
\hline $796 \mathrm{~B}-12 \mathrm{R}-2,32-36$ & 264.12 & Mudstone & 65 & 35 & 21.9 & 24.5 & $\mathrm{a} 17.0$ \\
\hline $796 \mathrm{~B}-15 \mathrm{R}-2,50-54$ & 293.30 & Siliceous mudstone & 78 & 22 & 24.4 & 26.5 & ${ }^{a} 16.9$ \\
\hline $796 \mathrm{~B}-18 \mathrm{R}-1,102-106$ & 321.42 & Siliceous mudstone & 0 & 100 & 18.0 & - & ${ }^{\mathrm{a}} 18.0$ \\
\hline $796 \mathrm{~B}-30 \mathrm{R}-2,102-106$ & 433.72 & Siliceous mudstone & 0 & 100 & 20.6 & - & 20.6 \\
\hline $796 \mathrm{~B}-33 \mathrm{R}-1,71-75$ & 455.91 & Porcellanite & 0 & 100 & 14.9 & - & ${ }^{a} 14.9$ \\
\hline $797 A-32 X-5,115-120$ & 299.05 & Chert & 88 & 12 & 27.4 & 30.2 & ${ }^{\mathrm{a}} 6.9$ \\
\hline $797 \mathrm{~A}-35 \mathrm{X}-3,12-16$ & 324.02 & Chert & 91 & 9 & 20.0 & 22.5 & 2.0 \\
\hline $797 A-38 X-1,142-146$ & 351.42 & Chert & 89 & 11 & 27.4 & 29.2 & ${ }^{\mathrm{a}} 12.8$ \\
\hline $797 \mathrm{~A}-43 \mathrm{X}-1,53-57$ & 398.13 & Siliceous mudstone & 92 & 8 & 26.2 & 27.4 & ${ }^{a} 12.1$ \\
\hline $797 A-45 X-1,2-6$ & 417.02 & Siliceous mudstone & 93 & $\begin{array}{l}0 \\
7\end{array}$ & 28.1 & 28.9 & a 17.3 \\
\hline $797 \mathrm{~A}-46 \mathrm{X}-1,146-150$ & 428.06 & Siliceous mudstone & 0 & 100 & 24.2 & - & 24.2 \\
\hline $797 A-48 X-2,106-110$ & 448.46 & Siliceous mudstone & 0 & 100 & 22.2 & - & 22.2 \\
\hline $797 A-49 X-4,3-7$ & 460.30 & Siliceous mudstone & 0 & 100 & 23.6 & - & 23.6 \\
\hline
\end{tabular}

The relative weight percentages of opal-CT and quartz refer to the chemically isolated samples.

${ }^{\text {a }}$ Mean values.

water. At each site, we paired the pore water $\delta^{18} \mathrm{O}$ value at the top of the opal-CT zone with each opal-CT $\delta^{18} \mathrm{O}$ value within the zone to compute formation temperatures of opal-CT. Similarly, to compute formation temperatures of diagenetic quartz, we used the water values at the top of the quartz zone at each site. This approach follows the observations and logic of Murata et al. (1977), namely, that opal-CT and quartz retain the isotopic compositions acquired at the time of formation until they dissolve (e.g., Fig. 2). The alternative of selecting pore water samples taken from depths which are closest to each silica sample would have made little difference in computed formation temperatures of the diagenetic silica because the isotopic depletion gradients of the pore waters are small.

Table 4 summarizes the isotopic temperatures for the diagenetic silica samples of this study computed in this manner, and Figure 4 plots these results along with the sediment temperature measurements and extrapolated present thermal gradients listed in Table 1. As a first approximation, the general clustering of isotopic temperatures near the extrapolated present-day sediment temperatures supports the notion that the silica transformations are controlled by the present thermal regime. For all sites, the scatter in values suggests that the method has a maximum uncertainty of about $25^{\circ} \mathrm{C}$. The ramification of this simple interpretation is that the silica transitions represent approximate isotherms. When tied to seismic reflection data, they provide a regional look at present gradient and heat flow variation in the eastern Japan Sea (e.g., Tamaki, Pisciotto, Allan, et al., 1990; Kuramoto et al., this volume).

Alternative interpretations of these data are possible if we consider the apparent deviations of the isotopically derived temperatures and gradients from those derived from sediment temperature probe measurements at these sites. Sites 794 and 797 in the Yamato Basin perhaps represent the simplest cases. At Site 794 isotopic temperatures fall evenly about the extrapolated sediment temperatures, suggesting that the silica zones have roughly equilibrated with the modern gradient (Fig. 4). In contrast, the past gradient, computed from the isotopic data in the manner of Murata et al. (1977) from the average opal-CT and quartz isotopic temperatures and the thickness of the opal-CT zone, is considerably less than the present gradient (Table 5). Given the scatter in the data, we favor the first interpretation for this site. At Site 797 all but one of the isotopic temperatures are lower than the extrapolated sediment temperatures at comparable depths. This systematic difference suggests that the silica zones have not yet adjusted to the present, warmer subsurface temperatures. This is supported by a computed thermal gradient which is slightly lower than the present gradient (Table 5).

At Site 795 isotopic temperatures are systematically lower than ambient temperatures at comparable depths but the computed gradient is considerably greater than the present one. If these mean isotopic temperatures are accurate, then we must explain the apparent dichotomy of lower past temperatures and a higher gradient. For both scenarios to hold, the silica zones must have formed under initially high gradients, were then buried rapidly during the Pliocene and Quaternary, and have yet to equilibrate with the present lower gradient. Relatively high sedimentation rates for the PliocenePleistocene sections at these sites support this interpretation (Tamaki, Pisciotto, Allan, et al., 1990). Further, the higher past gradient recorded by the isotopes may be representative of the early post-rift period in these two areas. Rifting and rapid subsidence of short duration ( 2-5 m.y.), evident at both sites (Ingle, this volume), was likely accompanied by an initial heat pulse and subsequent decay (McKenzie, 1978). 

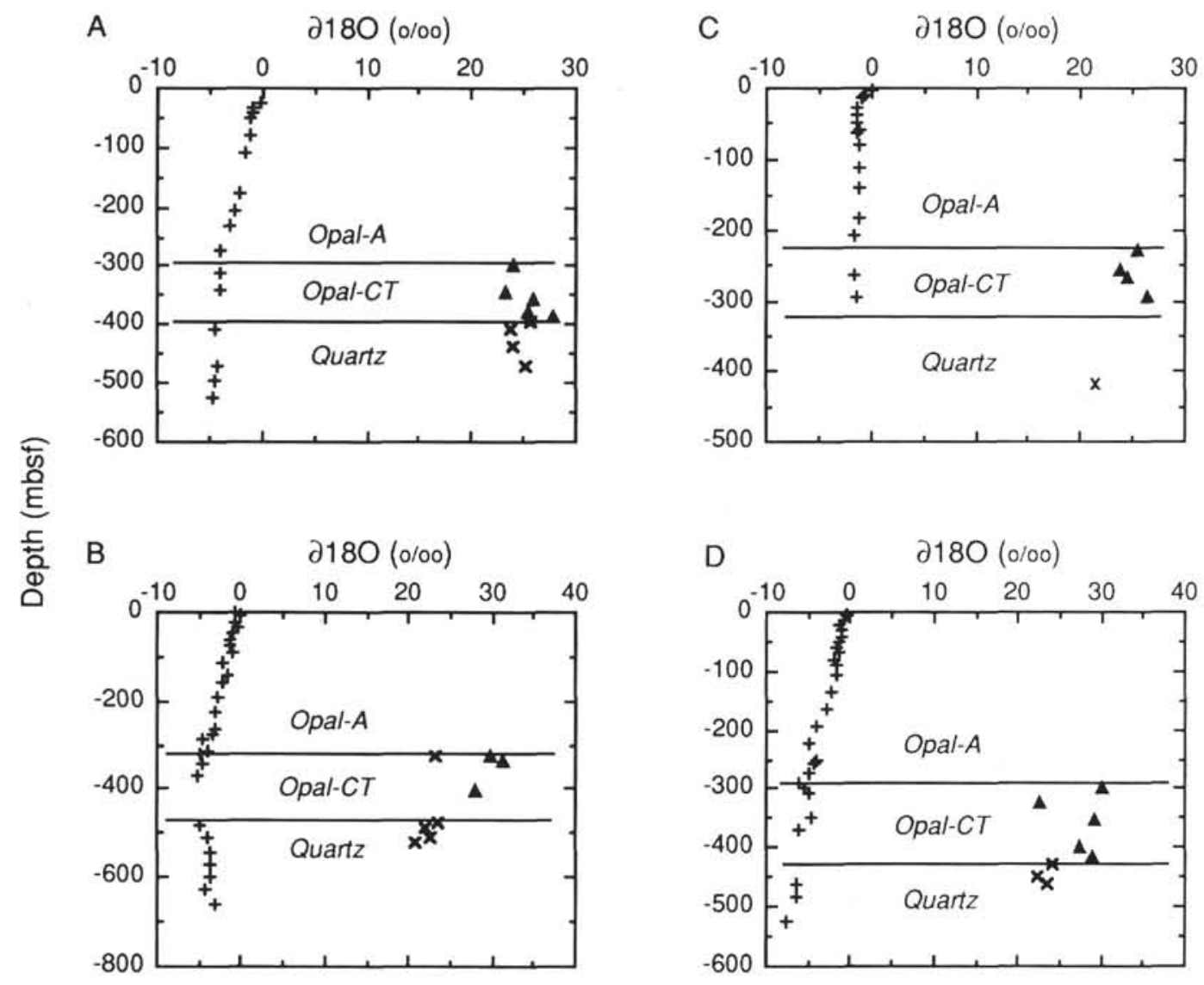

Figure 3. Oxygen isotopes vs. depth for pore waters (+), opal-CT (A), and diagenetic quartz (x), ODP Leg 127 sites. A. Site 794. B. Site 795. C. Site 796. D. Site 797.

At Site 796, all isotopic temperatures exceed present temperatures, as expected for an area of recent uplift (Fig. 4). Our computation of the past gradient from the isotopic data indicates that it was somewhat higher than at present (Table 5). If real, the high past and present gradients could reflect the higher initial heat fluxes associated with rapid rifting. Alternatively, or additionally, both sets of gradients may be the result of frictional heating from reverse fault activity near this site (Tamaki, Pisciotto, Allan, et al., 1990; Langseth and Tamaki, this volume).

\section{CONCLUSIONS}

Our isotopic study of Neogene diatomaceous sediments and associated pore waters in the eastern Japan Sea illustrates that silica transformations occurred over restricted temperature ranges of $22^{\circ}-68^{\circ} \mathrm{C}$ for opal-CT and $44^{\circ}-92^{\circ} \mathrm{C}$ for diagenetic quartz, quite similar to the temperature ranges estimated from the extrapolated modern gradients, $36^{\circ}-43^{\circ} \mathrm{C}$ and $49^{\circ}-64^{\circ} \mathrm{C}$, respectively. As a first approximation, these transformation temperatures represent crude isotherms. When tied to seismic reflection data, these "isotherms" provide an estimate of the variations of gradients and heat flow in the region (e.g., Kuramoto et al., this volume).

In detail, mean isotopic temperatures for opal-CT and diagenetic quartz differ somewhat from extrapolated sediment temperatures at the tops of these zones. At Sites 794 and 797 in the Yamato Basin, isotopic temperatures and gradients computed from these data are lower than or comparable to ambient temperatures and gradients, suggesting that the silica zones have roughly equilibrated with the modern gradients at these localities. At Site 795 in the Japan Basin, isotopic temperatures are also lower than sediment temperatures at comparable depths, but the computed gradients are higher than the measured present gradients. To account for this apparent dichotomy, the silica zones must have formed under initially high gradients during the early post-rift period at this locality. These zones were then rapidly buried and have yet to equilibrate with the modern lower gradient. At Site 796 on Okushiri Ridge, isotopic temperatures exceed present temperatures as expected for an area of recent uplift. Our isotopic data indicate a higher gradient than at present at this site, apparently reflecting higher heat fluxes during the early post-rift period or recent frictional heating from nearby reverse fault activity.

\section{ACKNOWLEDGMENTS}

We thank C. Lithgow for much of the initial sediment sample preparation and XRD work for this study, and our colleagues on Leg 127 for their enthusiasm, hard work, and scientific input. We also thank M. Field for help in the preparation of the manuscript and R. Siever and N. Hinman for their thoughtful reviews. This project was funded by the U.S. Science Program, and we gratefully acknowledge this support. The U.S. Science Program is associated with the Ocean Drilling Program and is sponsored by the National Science Foundation and Joint Oceanographic Institutions, Inc. Any opinions, findings, and conclusions or recommendations expressed in this publication are those of the authors and do not necessarily reflect the views of the National Science Foundation, the Joint Oceanographic Institutions Inc., or Texas A\&M University. 


\section{REFERENCES}

Bohrmann, G., Kuhn, G., Abelmann, A., Gersonde, R., and Fütterer, D. A., 1990. A young porcellanite occurrence from the Southwest Indian Ridge. Mar. Geol., 92:155-163.

Botz, R., and Bohrmann, G., in press. Low temperature opal-CT precipitation in Antarctic deep sea sediments: evidence from oxygen isotopes. Earth Planet. Sci. Lett.

Clayton, R. N., and Mayeda, T. K., 1963. The use of bromine pentafluoride in the extraction of oxides and silicates for isotopic analysis. Geochim. Cosmochim. Acta, 27:43-52.

Clayton, R. N., O'Neil, J., and Mayeda, T. K., 1972. Oxygen isotope exchange between quartz and water. J. Geophys. Res., 77:3057-3067.

Gieskes, J. M., 1981. Deep-Sea Drilling interstitial water studies: implications for chemical alteration of the oceanic crust, layers I and II. In Warme, J. E., Douglas, R. G., and Winterer, E. L. (Eds.)., The Deep Sea Drilling Project: A Decade of Progress. Spec. Publ.-Soc. Econ. Paleontol. Mineral., 32:149-167.

Gieskes, J. M., and Lawrence, J. R., 1981. Alteration of volcanic matter in deep sea sediments: evidence from the chemical composition of interstitial waters from Deep Sea Drilling cores. Geochim. Cosmochim. Acta, 45:1687-1703.

Ingle, J. C., Jr., Suyehiro, K., and von Breymann, M. T., et al., 1990. Proc. ODP, Init. Repts., 128: College Station, TX (Ocean Drilling Program),

Jenden, P. D., and Gieskes, J. M., 1983. Chemical and isotopic composition of interstitial water from Deep Sea Drilling Project Sites 533 and 534. In Sheridan, R. E., Gradstein, F. M., et al., Init. Repts. DSDP, 76: Washington (U.S. Govt. Printing Office), 453-461.

Kastner, M., 1981. Authigenic silicates in deep sea sediments: formation and diagenesis. In Emiliani, C. (Ed.), The Sea (Vol. 7): New York (Wiley), 915-980.

Kishima, N., and Sakai, H., 1980. Oxygen-18 and deuterium determination on a single water sample of a few milligrams. Anal. Chem., 52:356-358.

Kita, I., Taguchi, S., and Matsubaya, O., 1985. Oxygen isotope fractionation between amorphous silica and water at $34^{\circ}-93^{\circ} \mathrm{C}$. Nature, $314: 83-84$
Leclerc, A. J., and Labeyrie, L., 1987. Temperature dependence of the oxygen isotopic fractionation between diatom silica and water. Earth Planet. Sci. Lett., 84:69-74.

Manheim, F. T., and Sayles, F. L., 1974. Composition and origin of interstitial waters of marine sediments based on deep sea drill cores. In Goldberg, E. D. (Ed.), The Sea (Vol. 5): New York (Wiley), 527-568.

McKenzie, D., 1978. Some remarks on the development of sedimentary basins. Earth Planet. Sci. Lett., 40:25.

Mizutani, S., 1970. Silica minerals in the early stage of diagenesis. Sedimentology, 15:419-436.

Murata, K. J., Friedman, I., and Gleason, J. D., 1977. Oxygen isotope relations between diagenetic silica minerals in Monterey Shale. Am. J. Sci., 277:259-272.

Murata, K. J., and Larson, R. R., 1976. Diagenesis of Monterey siliceous shales, Temblor Range, California. J. Res. U.S. Geol. Surv., 3:553-566.

Perry, E. A., Gieskes, J. M., and Lawrence, J. R., 1976. Mg, Ca, and ${ }^{18} \mathrm{O} /{ }^{16} \mathrm{O}$ exchange in the sediment-pore water system, Hole 149, DSDP. Geochim. Cosmochim. Acta, 40:413-423.

Pisciotto, K. A., 1978. Basinal sedimentary facies and diagenetic aspects of the Monterey Shale, California [Ph.D. dissert.]. Univ. California, Santa Cruz.

, 1981a. Diagenetic aspects of the siliceous facies of the Monterey Shale in the Santa Maria region, California. Sedimentology, 28:547-571.

- 1981b. Distribution, thermal histories, isotopic compositions and reflection characteristics of siliceous rocks recovered by the Deep Sea Drilling Project. In Warme, J. E., Douglas, R. G., and Winterer, E. L. (Eds.), The Deep Sea Drilling Project: A Decade of Progress. Spec. Publ.-Soc. Econ. Paleontol. Mineral., 32:129-147.

Tamaki, K., Pisciotto, K., Allan, J., et al., 1990. Proc. ODP, Init. Repts., 127: College Station, TX (Ocean Drilling Program).

Weaver, F. M., and Wise, S. W., 1973. Early diagenesis of deep sea bedded cherts. Antarct. J., 228-230.

Date of initial receipt: 18 March 1991

Date of acceptance: 6 December 1991

Ms 127/128B-113

Table 4. Computed isotopic temperatures for opal-CT and diagenetic quartz, ODP Sites 794-797.

\begin{tabular}{|c|c|c|c|}
\hline $\begin{array}{l}\text { Hole, core, section } \\
\text { interval }(\mathrm{cm})\end{array}$ & $\begin{array}{l}\text { Depth } \\
\text { (mbsf) }\end{array}$ & $\begin{array}{l}\text { Opal-CT temperature } \\
\left({ }^{\circ} \mathrm{C}\right)\end{array}$ & $\begin{array}{l}\text { Quartz temperature } \\
\qquad\left({ }^{\circ} \mathrm{C}\right)\end{array}$ \\
\hline $794 \mathrm{~A}-32 \mathrm{X}-3,146-150$ & 297.96 & 56 & \\
\hline $794 \mathrm{~B}-37 \mathrm{X}-1,54-58$ & 342.14 & 59 & \\
\hline 794B-7R-1, 14-18 & 356.74 & 47 & \\
\hline 794B-9R-1, 56-60 & 376.56 & 50 & \\
\hline $794 \mathrm{~B}-10 \mathrm{R}-1,16-20$ & 385.76 & 39 & \\
\hline 794B-1IR-CC, $16-20$ & 396.06 & & 47 \\
\hline $794 \mathrm{~B}-12 \mathrm{R}-2,7-11$ & 406.47 & & 56 \\
\hline $794 \mathrm{~B}-15 \mathrm{R}-2,28-32$ & 435.58 & & 54 \\
\hline $794 \mathrm{~B}-18 \mathrm{R}-5,6-10$ & 468.66 & & 50 \\
\hline $795 A-35 X-6,5-9$ & 325.15 & 28 & \\
\hline $795 \mathrm{~A}-37 \mathrm{X}-1,81-85$ & 337.71 & 22 & \\
\hline 795B-5R-1, 90-94 & 405.00 & 34 & \\
\hline 795B-12R-3, 54-58 & 474.94 & & 55 \\
\hline 795B-13R-3, 1-5 & 484.01 & & 63 \\
\hline $795 \mathrm{~B}-16 \mathrm{R}-1,127-131$ & 510.97 & & 60 \\
\hline $795 \mathrm{~B}-17 \mathrm{R}-1,91-94$ & 520.31 & & 69 \\
\hline $796 \mathrm{~A}-26 \mathrm{X}-2,101-105$ & 226.01 & 63 & \\
\hline $796 \mathrm{~B}-11 \mathrm{R}-2,62-66$ & 254.82 & 72 & \\
\hline $796 \mathrm{~B}-12 \mathrm{R}-2,32-36$ & 264.12 & 68 & \\
\hline $796 \mathrm{~B}-15 \mathrm{R}-2,50-54$ & 293.30 & 57 & \\
\hline 796B-30R-2, 102-106 & 433.72 & & 92 \\
\hline $797 \mathrm{~A}-32 \mathrm{X}-5,115-120$ & 299.05 & 24 & \\
\hline $797 \mathrm{~A}-35 \mathrm{X}-3,12-16$ & 324.02 & 57 & \\
\hline $797 \mathrm{~A}-38 \mathrm{X}-1,142-146$ & 351.42 & 27 & \\
\hline $797 A-43 X-1,53-57$ & 398.13 & 34 & \\
\hline $797 A-45 X-1,2-6$ & 417.02 & 28 & \\
\hline $797 \mathrm{~A}-46 \mathrm{X}-1,146-150$ & 428.06 & & 44 \\
\hline $797 \mathrm{~A}-48 \mathrm{X}-2,106-110$ & 448.46 & & 54 \\
\hline $797 \mathrm{~A}-49 \mathrm{X}-4,3-7$ & 460.03 & & 47 \\
\hline
\end{tabular}



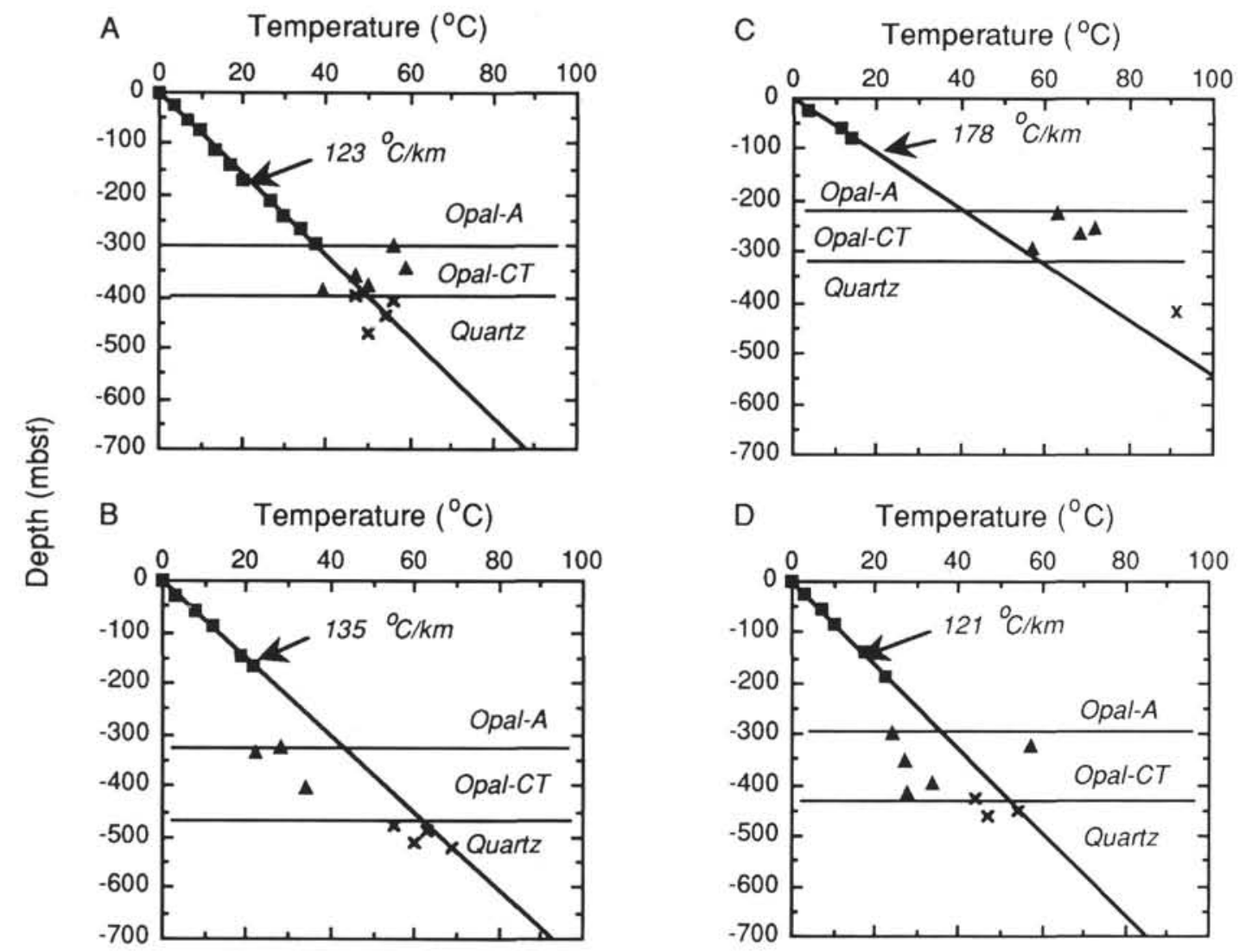

Figure 4. Temperatures vs. depth for ODP Leg 127 sites. Data include (1) sediment temperatures (®) acquired during drilling with the heat flow probe and (2) temperatures computed from oxygen isotopes of opal-CT ( $\mathbf{\Delta})$ and diagenetic quartz (x). The thermal gradients shown are computed from the heat flow probe measurements and extrapolated linearly. A. Site 794. B. Site 795. C. Site 796. D. Site 797.

Table 5. Summary of subsurface and isotopic temperatures and computed thermal gradients, ODP Sites 794-797.

\begin{tabular}{|c|c|c|c|c|c|c|}
\hline \multirow[b]{2}{*}{ Site } & \multicolumn{2}{|c|}{ Isotopic temperature $\left({ }^{\circ} \mathrm{C}\right)^{a}$} & \multirow{2}{*}{$\begin{array}{l}\text { Sediment temperature } \\
\left({ }^{\circ} \mathrm{C}\right)\end{array}$} & \multirow{2}{*}{$\begin{array}{l}\text { Depth } \\
\text { (mbsf) }\end{array}$} & \multicolumn{2}{|c|}{ Gradient $\left({ }^{\circ} \mathrm{C} / \mathrm{km}\right)$} \\
\hline & Opal-CT & Quartz & & & Isotopic & Sedimen \\
\hline 794 & 50 & & 37 & 290 & $19 ?$ & 126 \\
\hline 794 & & 52 & 50 & 395 & & \\
\hline 795 & 28 & & 44 & 325 & 233 & 135 \\
\hline 795 & & 62 & 64 & 471 & & \\
\hline 796 & 65 & & 40 & 225 & 270 & 178 \\
\hline 796 & & 92 & 58 & $325 ?$ & & \\
\hline 797 & 34 & & 36 & 299 & 105 & 121 \\
\hline 797 & & 48 & 52 & 432 & & \\
\hline
\end{tabular}

${ }^{\mathrm{a}}$ Mean values. 